\title{
PENYULUHAN TENTANG INTERNET SEHAT DAN ETIKA-NYA UNTUK MASYARAKAT DESA SURANADI KABUPATEN LOMBOK BARAT PROVINSI NTB
}

\author{
I Gede Pasek Suta Wijaya ${ }^{1 *}$, Ida Bagus Ketut Widiartha ${ }^{1)}$, Fitri Bimantoro ${ }^{1)}$, Ario \\ Yudo Husodo1), Gibran Satya Nugraha1) \\ 1)Program Studi Teknik Informatika, Universitas Mataram \\ Jalan Majapahit Nomor 62, Kota Mataram, Provinsi Nusa Tenggara Barat \\ *alamat korespondensi: gpsutawijaya@unram.ac.id
}

\begin{abstract}
ABSTRAK
Teknologi informasi dan komunikasi berbasis internet telah menjadi primadona dan sumber informasi utama dalam komunikasi antar manusia. Jaringan internet juga telah menyebabkan dunia seolah tanpa jarak dan batas. Internet dengan cepatnya merambah ke berbagai aspek kehidupan mulai dari kalangan bisnis, masyarakat umum, dan pencari berita. Kelebihan jaringan internet tersebut beriring dengan kelemahannya yang juga dapat menimbulkan permasalahan baru. Jika dikaitkan dengan kontennya maka internet menyedia informasi baik yang bersifat positif maupun negatif. Informasi negatif berbasis jaringan internet ini meliputi judi, pornografi, berita hoax, pembulian,dan lain sebagainya. Konten-konten negatif ini sangat berbahaya bagi masyarakat khususnya bagi generasi muda. Kegiatan pengabdian kepada masyarakat ini bertujuan untuk menghindari pengaruh-pengaruh negatif yang muncul akibat penggunaan internet. Topik utama yang diangkat dalam kegiatan ini adalah tentang pengaruh perkembangan teknologi informasi dan komunikasi bagi masyarakat pada era globalisasi, khususnya tentang internet sehat dan etika berkomunikasi di dunia Maya. Kegiatan penyuluhan ini dilaksankan di Desa Suranadi, Kabupaten Lombok Barat. Penyuluhan yang dilakukan meliputi pemaparan materi oleh berbagai narasumber mengenai dampak positif dan negatif dari internet, serta tips memperolah keuntungan atau penghasilan yang bersumber dari internet. Hasil yang didapatkan adalah masyarakat Desa Suranadi sebagian besar belum benar-benar memahami cara ber-internet secara sehat dan baik, sehingga pelatihan-pelatihan seperti ini perlu dilakukan secara terusmenerus baik di Desa Suranadi maupun desa-desa lainnya di Kabupaten Lombok Barat.
\end{abstract}

Kata kunci: internet sehat, dunia maya, desa suranadi 


\section{PENDAHULUAN}

Perkembangan teknologi informasi dan komunikasi khususnya Internet di era globalisasi sekarang ini, tidak dapat lagi dibendung keberadaannya. Sehingga, pengguna dari teknologi informasi bersifat masif di kalangan masyarakat mulai dari anak-anak, remaja, hingga orang tua. Berdasarkan data pengguna Internet di Indonesia tahun 2016, bahwa jumlah pelanggan mencapai 132,7 juta orang atau sekitar $51,5 \%$ dari total jumlah penduduk Indonesia sebesar 256,2 juta. Pengguna internet terbanyak berada di pulau Jawa sebanyak 86.339 .350 pengguna atau sekitar $65 \%$. Untuk pengguna di Bali Nusra adalah sebanyak 6.184.796 pelanggan atau sekitar 4,67\% (Apiji 2017; KomInfo 2015). Di kawasan Asia Tenggara, Indonesia merupakan pasar internet dengan pertumbuhan tercepat di dunia, yakni sebanyak 260 juta pengguna pada 2016. Berdasarkan data di atas, internet telah menjadi primadona baru dalam komunikasi antar manusia dan telah menjadi sumber informasi utama. Internet juga telah menyebabkan dunia menjadi tanpa jarak dan tanpa batas negara. Sehingga, pemanfaatan internet di Indonesia telah merambah ke berbagai aspek kehidupan mulai dari kalangan bisnis, masyarakat umum, dan pencari berita
Sebagaimana disebutkan diatas bahwa Internet menawarkan banyak manfaat dan kemudahan basi masyarakat. Sebagai sumber informasi melalui mesin pencarinya, internet menyediakan banyak informasi yang dapat diakses dengan mudah dan cepat. Sebagai sumber ilmu pengetahuan, internet menyediakan berbagai materi pengetahuan, pembelajaran dan tutorial. Terlebih lagi dengan adanya telepon pintar yang banyak memberikan kemudahan bagi penggunannya.

Di samping berbagai kelebihan fitur internet yang telah diuraikan bahwa internet juga memiliki kelemahan terutama berkaitan dengan kontennya. Jika dikaitkan dengan kontennya maka internet menyedia informasi yang positif maupun negatif (Astuti dkk, 2016; Hidayanto dan IImi 2015; Tim Internet Sehat 2016). Informasi positif meliputi informasi pendidikan, kesehatan, berita, e-commerce, dan lain sebagainya. Sedangkan informasi negatif meliputi judi, pornografi, berita hoax, pembulian, dan lain sebagainya. Konten-konten negatif ini sangat berbahaya bagi masyarakat khususnya bagi generasi muda.

Ditinjau dari aspek komunikasi, komunikasi di internet yang sering disebut dengan komunikasi dunia maya juga rentan akan dampak negatif seperti komunikasi tanpa etika dengan pembenaran kebebasan 
berekspresi. Kebebasan berekspresi sesungguhnya merupakan suatu hak menyampaikan ide/isi pikiran yang dilandasi oleh sikap yang bertanggung jawab. Sehingga berbagai bentuk ekspresi di dunia maya harus berpedoman pada etika yang berlaku agar pengguna tidak terjebak pada kebebasan berekspresi tanpa tanggung jawab.

Secara rinci dampak positif yang ditimbulkan oleh internet dapat diuraikan sebagai berikut:

1. Internet sebagai media komunikasi, merupakan fungsi dari internet yang paling banyak digunakan dimana setiap pengguna internet dapat berkomunikasi dengan pengguna lainnya secara real-time tanpa mengenal jarak dan waktu.

2. Media pertukaran data, dengan menggunakan email, newsgroup, ftp dan www (world wide web jaringan situs-situs web) dan media sosial memungkinkan para pengguna internet di seluruh dunia dapat saling bertukar informasi dengan cepat dan murah.

3. Media untuk mencari informasi atau data, melalui mesin pencari bahwa internet merupakan salah satu sumber informasi yang penting dan akurat yang banyak digunakan oleh masyarakat.

4. Kemudahan memperoleh informasi yang ada di internet sehingga manusia tahu apa saja yang terjadi.

5. Bisa digunakan sebagai lahan informasi untuk bidang pendidikan, kebudayaan, dan lain-lain.

6. Kemudahan bertransaksi dan berbisnis dalam bidang perdagangan sehingga tidak perlu pergi menuju ke tempat penawaran/penjualan (Purbo dan Arif W 2001; StartUpBisnis 2015).

Disamping manfaat positif yang dapat diperoleh dari dunia maya, ada beberapa kejahatan (dampak negatif) yang telah muncul dan terjadi di dunia internet, antara lain:

1. Carding atau memalsukan nomor kartu kredit orang lain untuk bisa mendatangkan berbagai produk komersial yang diperjual belikan lewat internet

2. Hacking atau merusak/mengacaukan jaringan komputer pihak lain

3. Pornografi melalui internet.

4. Perederan narkoba melalui internet

5. Pengedaran program komputer tanpa izin

6. Pencemaran nama baik lewat Internet

7. Cracking, phreaking dan serangan virus atau worm

8. Berita Hoax (Bohong)

9. Pembulian 
10. Kejahatan

penipuan, perdagangan manusia, prostitusi, dan terorisme

11. Kecanduan

Oleh karena itu, untuk menghindari pengaruh-pengaruh negatif yang muncul akibat penggunaan internet maka diperlukan suatu kegiatan penyuluhan terkait dengan pengaruh perkembangan teknologi informasi dan komunikasi bagi masyarakat pada era globalisasi, khususnya tentang internet sehat dan etika berkomunikasi di dunia maya. Kegiatan penyuluhan ini diharapkan para masyarakat khususnya desa Suranadi dapat mengetahui lebih jauh tentang pengaruh yang ditimbulkannya baik yang berdampak positif maupun negative yang ditimbulkan dari perkembangan teknologi di era globalisasi dan bagaimana menghindarinya supaya pengguna tidak sampai terkena kasus hukum.

\section{METODE KEGIATAN}

Kegiatan penyuluhan ini dilaksanakan secara bertahap yang diawali dengan survey lokasi dan meminta kesediaan masyarakat untuk mengikuti penyuluhan. Selanjutnya, secara teknis pelaksanaan kegiatan ini berupa penyuluhan dan diskusi tentang internet sehat dan etikanya. Adapun peralatan yang diperlukan:
1. Seperangkat komputer yang terhubung dengan internet;

2. LCD projector; dan

3. Materi pelatihan.

4. Snack sebagai perangsang kegiatan

Ada dua materi besar yang akan disampaikan pada kegiatan ini, yaitu materi Internet sehat dan Etika berinternet. Untuk Internet sehat materinya meliputi:

1. Gerakan internet sehat

2. Penekanan internet sehat

3. Bagaimana berinternet sehat

4. Tools yang mendukung internet sehat

Sedangkan kaitan dengan etikanya, mengapa etika dalam dunia maya penting untuk diketahui dan dipatuhi adalah sebagai berikut:

1. Bahwa pengguna internet berasal dari berbagai negara yang mungkin memiliki budaya, bahasa dan adat istiadat yang berbedabeda.

2. Pengguna internet merupakan orang-orang yang hidup dalam dunia anonymous, yang tidak mengharuskan pernyataan identitas asli dalam berinteraksi.

3. Berbagai macam fasilitas yang diberikan dalam internet memungkinkan seseorang untu bertindak etis seperti misalnya ada juga penghuni yang suka nakal.

4. Harus diperhatikan bahwa pengguna internet akan selalu bertambah setiap saat dan memungkinkan masuknya 
"penghuni" baru di dunia maya tersebut.

Secara umum point-point etika yang hendaknya dipatuhi dalam berkomunikasi di dunia maya adalah sebagai berikut:

1. Jangan gunakan huruf kapital

2. Kutip seperlunya saja

3. Perlakuan terhadap pesan pribadi

4. Hati-hati terhadap informasi/ berita hoax

5. Hindari personal attack

6. Kritik dan saran yang bersifat pribadi harus lewat PM (Personal Message)

7. Dilarang menghina

8. Cara bertanya yang baik

Disamping itu juga akan dibahas etika ber-email, chatting, dan komentar melalui di sosial media. Evaluasi kegiatan penyuluhan internet sehat dan etikanya dilaksanakan pada saat pelaksanaan kegiatan dengan melihat partisipasi peserta dalam mengikuti penyuluhan, pemahaman materi, dan mempraktekkan proses komunikasi sehat di Internet. Disamping itu, komunikasi lanjutan dapat dilakukan melalui email, WA, Facebook untuk melakukan diskusi tentang internet sehat dan perubahan pola dalam penggunaan internet.

\section{HASIL DAN PEMBAHASAN}

Dari kegiatan pengabdian kepada masyarakat yang telah dilakukan terhadap masyarakat
Suranadi diketahui bahwa etika penggunaan internet belum banyak diketahui atau dipahami oleh masyarakat. Masyarakat Suranadi masih belum dapat menilai konten internet yang lebih menjurus ke arah negatif maupun positif.

Pada kegiatan ini, masyarakat memiliki antusiasme yang tinggi terhadap penyuluhan internet sehat yang dilakukan dapat dilihat pada Gambar 1 dan Gambar 2, selama penyuluhan dan sesi tanya jawab peserta banyak mengajukan pertanyaan mengenai maraknya penyebaran hoax, ujaran kebencian, maupun pornografi pada saat berselancar di dunia internet, dapat dilihat pada Gambar 3 dan Gambar 4. Selain itu, masyarakat juga memiliki motivasi yang kuat untuk dapat menggunakan internet dalam berwiausaha seperti jual beli, promosi keterampilan lokal, maupun mengakses materi yang berkaitan dengan pendidikan.

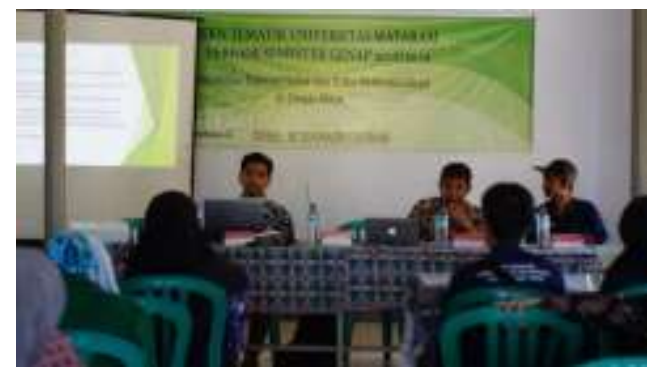

Gambar 1. Pemaparan materi internet sehat oleh penyaji. 


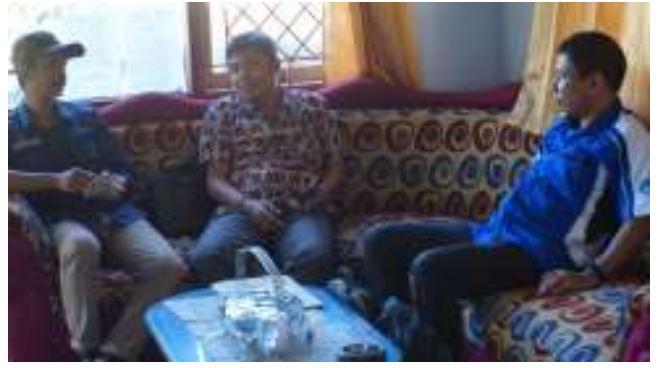

Gambar 2. Diskusi antara penyaji dan peserta.

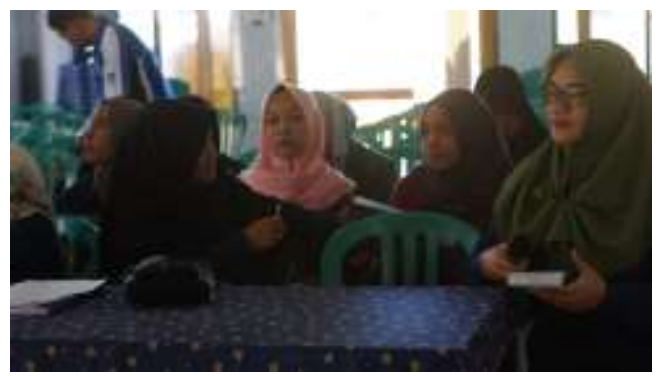

Gambar 3. Antusiasme peserta yang mengikuti penyuluhan Faktor Pendukung.

Beberapa faktor pendukug keberhasilan kegiatan ini, antara lain:

1. Motivasi dan kerja keras tim untuk melaksanakan kegiatan dengan baik

2. Dukungan dari pihak Program Studi Teknik Informatika maupun Fakultas Teknik Universitas Mataram dalam hal penyediaan dana dan materi pendukung

3. Kerjasama yang baik dengan perangkat dan masayarakat Desa Suranadi.

4. Antusiasme dan partisipasi aktif seluruh peserta kegiatan dalam mengikuti pemaparan dan diskusi yang dipandu oleh tim pengabdian kepada masyarakat.

\section{Faktor Penghambat}

Dalam pelaksanaan kegiatan ini, tim pengabdian tidak menemui kendala dan hambatan. Kegiatan berjalan sesuai dengan jadwal yang telah disepakati oleh tim pengabdian masyarakat, perangkat desa, maupun masyarakat Desa Suranadi.

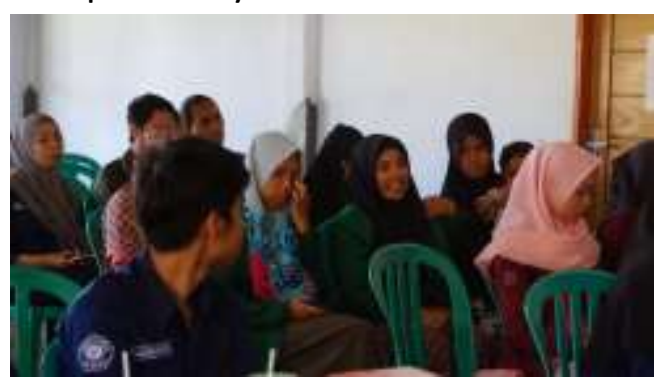

Gambar 4. Peserta pelatihan banyak berasal dari golongan muda maupun orang tua.

\section{KESIMPULAN DAN SARAN}

\section{Kesimpulan}

Berdasarkan hasil pengamatan dari kegiatan pengabdian kepada masyarakat yang telah dilakukan, maka dapat disimpulkan hal-hal sebagai berikut :

1. Pelaksanaan kegiatan pengabdian kepada masyarakat dapat berjalan dengan baik dengan adanya komunikasi yang aktif antara tim pengabdian kepada masyarakat perangkat desa, maupun masyarakat Desa Suranadi

2. Kegiatan yang dilakukan merupakan upaya untuk mengedukasi masyarakat Suranadi mengenai internet sehat dan etika yang mesti dipatuhi 
pada saaat berselancar di dunia internet.

3. Materi yang disampaikan dapat menarik perhatian masyarakat yang hadir pada kegiatan tersebut karena disajikan dalam berbagai media, seperti audio dan video.

\section{Saran}

Untuk maksimalnya hasil kegiatan pengabdian masyarakat, maka diberikan saran-saran sebagai berikut:

1. Kegiatan pengabdian kepada masyarakat dengan tema ini perlu dilaksanakan di daerah-daerah lainnya di Lombok Barat, untuk memberikan pemahaman yang memadai mengenai internet sehat.

2. Diperlukan komunikasi yang lebih aktif dari perangkat desa dan tim pengabdian, agar hasil kegiatan dapat dievaluasi secara intensif. Komunikasi dapat dilakukan melalui berbagai media, seperti telepon, email atau kunjungan langsung.

\section{UCAPAN TERIMA KASIH}

Tim pengabdian kepada masyarakat mengucapkan terima kasih kepada Lembaga Penelitian dan Pengabdian Kepada Masyarakat Universitas Mataram yang telah memberi kesempatan dan bantuan dana kepada kami untuk melaksanakan kegiatan ini, Ketua Program Studi Teknik Informatika yang telah mendukung kegiatan ini, perangkat Desa Suranadi dan warganya yang telah memberikan kesempatan untuk melakukan kegiatan pengabdian kepada masyarakat di daerahnya, dan Tim KKN Tematik Universitas Mataram Periode Genap 2018/2019 Desa Suranadi yang telah banyak membantu dalam koordinasi acara, serta berbagai pihak yang tidak bisa kami sebutkan satu persatu.

\section{DAFTAR PUSTAKA}

Apiji. 2017. "Survei Internet APJII 2016." https://www.apjii.or.id/conte nt/read/39/264/SurveiInternet-APJII-2017.

Astuti, Dyah S, Putri IP, and Fithrah S. 2016. "Strategi Komunikasi Program Internet Sehat Dan Aman Kementerian Komunikasi Dan Informatika Republik Indonesia ( Studi Kasus Evaluasi Program Incakap Tahun 2015." Jurnal Komunikasi 8(1):25-35.

Hidayanto F, IImi MZ. 2015. "Pentingnya Internet Sehat." Jurnal Inovasi Dan Kewirausahaan 4(1):21-24.

KomInfo. 2015. "Data Pengguna Internet Indonesia." : http://kominfo.go.id/index.ph $\mathrm{p} /$ content/detail/3980/Kemk ominfo\%3A+Pengguna+Intern et+di+Indonesia+Capai+82+Ju ta/0/berita_satker\#.VThpdJN $6 \mathrm{~N}-4$. 
Purbo OW, and Anang Arif W. 2001.

Mengenal E-Commerce. PT. Elex Media Komputindo.

Start Up Bisnis. 2015. “Data Statistik Pertumbuhan Pangsa Pasar ECommerce Di Indonesia.": http://startupbisnis.com/data -statistik-mengenaipertumbuhan-pangsa-pasar- e-commerce-di-indonesiasaat-ini/.

Tim Internet Sehat. 2016. "Literasi Digital Anak Membutuhkan Sinergi Banyak Pihak.": https://internetsehat.id/2016 /06/literasi-digital-anakmembutuhkan-sinergibanyak-pihak. 